\title{
Histostaining for Tissue Expression Pattern of Promoter-driven GUS Activity in Arabidopsis \\ Xiyan $\mathrm{Li}^{*}$
}

Department of Genetics, Stanford University, Stanford, USA

*For correspondence: lixiyan@stanford.edu

[Abstract] Promoter-driven beta-glucuronidase (GUS) activity is the most commonly used technique for tissue-specific expression patterns in Arabidopsis. In this procedure, the GUS enzyme converts 5-bromo-4-chloro-3-indolyl glucuronide (X-Gluc) to a blue product. The staining is very sensitive. Processed samples can be examined under dissecting microscope or Differential Interference Contrast (Nomaski) microscope for bright blue color over cleared transparent background. Note that this assay does not provide accurate information on subcellular levels.

\section{Materials and Reagents}

1. Transgenic plants that contain genomic integration of a promoter: GUS expression cassette

2. Potassium Ferrocyanide

3. Potassium Ferricyanide

4. Triton $\mathrm{X}-100$

5. $50 \mathrm{mM} \mathrm{NaHPO}_{4}$ buffer (pH 7.2)

6. Dimethylformamide (DMF)

7. Acetone

8. $\mathrm{NaHPO}_{4}$ buffer

9. 5-bromo-4-chloro-3-indolyl beta-D-glucuronide cyclohexamine salt (X-Gluc)

10. 200 proof ethanol (once opened, 200 proof becomes essentially 190 proof)

11. Staining buffer (see Recipes)

12. Stock solutions (see Recipes)

\section{Equipment}

1. Eppendorf tubes

2. Vacuum

3. Dissecting or light microscope 
4. Differential Interference Contrast (Nomaski) microscope

\section{Procedure}

1. Harvest tissue and place in cold $90 \%$ Acetone on ice. This should stay on ice until all samples are harvested. For sample containers, Eppendorf tubes and glass scintillation vials work well.

2. When all samples are harvested, place at room temperature (RT) for $20 \mathrm{~min}$.

3. Remove acetone from the samples, and add staining buffer on ice.

4. Add $X$ - Gluc to the staining buffer to a final concentration of $2 \mathrm{mM}$ from a $100 \mathrm{mM}$ stock solution of X-Gluc in DMF- this must be kept in the dark at $-20^{\circ} \mathrm{C}$.

5. Remove staining buffer from samples and add staining buffer with X-Gluc on ice.

Note: Do not infiltrate when make $L R$ embedding, instead infiltrate in the fixatives or $10 \%$ ethanol.

Infiltrate the samples under vacuum, on ice, for 15 to $20 \mathrm{~min}$. Release the vacuum slowly and verify that all the samples sink. If they don't, infiltrate again until they all sink to the bottom when the vacuum is released.

6. Incubate at $37^{\circ} \mathrm{C}$ (I usually do it for $2 \mathrm{~h}$ for strong promotors and up to overnight for weak promotors. It is not advisable from my experience to go too long (over two days) as the tissue seems to begin deteriorating during long incubations.

7. Remove samples from incubator and remove staining buffer.

8. Go through ethanol series from $10 \%, 30 \%, 50 \%, 70 \%$ (you may heat the sample to $60{ }^{\circ} \mathrm{C}$ to get rid of chloroplasts), to $95 \%$ (avoid light); 30 min each step and then finally $100 \%$. You may store at $4{ }^{\circ} \mathrm{C}$ for up to a month, seal well.

9. Go to embedding procedure, or observe directly under dissecting or light microscope. To mount, simply apply a few drops of water to the samples.

\section{$\underline{\text { Recipes }}$}

1. Staining buffer (final conc.) (fresh)

$0.2 \%$ Triton X-100 (may be reduced to $0.05 \%$ )

$50 \mathrm{mM} \mathrm{NaHPO}_{4}$ buffer (pH 7.2)

$2 \mathrm{mM}$ potassium Ferrocyanide

$2 \mathrm{mM}$ potassium Ferricyanide

Water to volume 
Note: Higher Ferricyanide and ferrocyanide concentrations give lower overall staining level, but more specificity. $2 \mathrm{mM}$ works well for most applications, but the concentrations may need to be adjusted for certain needs.

2. Stock solutions $\left(4^{\circ} \mathrm{C}\right)$

10\% Triton X-100

$0.5 \mathrm{M} \mathrm{NaHPO}_{4}$ buffer ( $\left.\mathrm{pH} 7.2\right)$

$100 \mathrm{mM}$ potassium Ferrocyanide (store in the dark at $4{ }^{\circ} \mathrm{C}$ )

$100 \mathrm{mM}$ potassium Ferricyanide (store in the dark at $4^{\circ} \mathrm{C}$ )

$100 \mathrm{mM} X$-Gluc in DMF

\section{$\underline{\text { References }}$}

1. Li, X., Chanroj, S., Wu, Z., Romanowsky, S. M., Harper, J. F. and Sze, H. (2008). A distinct endosomal $\mathrm{Ca}^{2+} / \mathrm{Mn}^{2+}$ pump affects root growth through the secretory process. Plant Physiol 147(4): 1675-1689.

2. Padmanaban, S., Chanroj, S., Kwak, J. M., Li, X., Ward, J. M. and Sze, H. (2007). Participation of endomembrane cation $/ \mathrm{H}^{+}$exchanger AtCHX20 in osmoregulation of guard cells. Plant Physiol 144(1): 82-93. 